\title{
Discussion on Key Selection Criteria For Successful Management Of Home Delivery
}

\author{
Yi-Hsueh Shen \\ Instructor/Department of Hospitality Management, Jen-teh Junior College of Medicine, Nursing \\ and Management, Miaoli, Taiwan \\ ian343.sdk@msa.hinet.net
}

\begin{abstract}
With the development of science and technology, the use of Internet has become more common, and the network economy and e-commerce have sprung up. The survey conducted by the DGBAS showed that Taiwan's Internet penetration rate was $67.7 \%$ in 2010, and the number of Internet users reached up to 17,260,000. Another network use survey conducted by DGBAS indicated that Taiwan's mobile Internet penetration rate reached $71.3 \%$ in 2010, which was 12,649,000 personal computers. In addition, according to Taiwan's broadband Internet use survey results, Taiwan's mobile Internet penetration rate was $47.27 \%$. These data showed that people spent more and more time on the Internet, which contributed to the booming of network economy, e-commerce and direct selling business, and created large business opportunities for home delivery industry.
\end{abstract}

Different customers may have different needs and their needs may change with different purposes, therefore this study first reviewed the literature to clarify the relevant factors. On the basis of cognition of the research topic, the expert concepts in the interviews were integrated to establish the theoretical foundation. The study determined the structure through modified Delphi expert questionnaire. Then with analytic hierarchy process, customer questionnaires were conducted, decision-making factors were ranked according to the importance degree, and market implementation plan that met the demands of market was summed up. The results showed that home delivery practitioners must have accurate and quick deliver ability, flexible prices, diversified service items and more convenient services to meet the needs of customers.

Keywords: home delivery, modified Delphi expert, analytic hierarchy process, selection criteria

\section{INTRODUCTION}

The use of the Internet platform has broken the convention of having storefront to do business. Moe and more people have participated in the network economy. With the features of convenience, rapidness, high permeability, strong persistence, large coverage, network economy and so on, network economy has prompted many manufacturers, wholesalers, retailers and even enterprises with their own physical stores business to develop the network business. With more resources investment, goods on the Internet and marketing practices were more and more diversified, so customers had more choices. The Internet store was virtual with no physical store, so the transaction must rely on home delivery to be completed, which was the reason for the development of home delivery, logistics and distribution, freight industries. The huge market interest has attracted practitioners of different industries to share the fruits. Hence, some emphasized on the timeliness, such as fast service and night delivery; some stressed the price, such as convenience bags and student parcels; some emphasized service characteristics, such as low temperature distribution and room temperature distribution; some stressed the convenience, such as pickup service, 24-hour service; and others stressed the credibility, such as corporate image and delivery quality, etc. If you can find out the key factors of home delivery, and the enterprise itself had enough resources to improve, it meant that the implementation of the program can meet the needs of the target market, and that the company in this complex marketing war can get the greatest benefits. 


\section{LITERATURE REVIEW}

\subsection{Home Delivery}

Home delivery came from the Japanese, which was also known as "Takuhaibin" in Japanese. The pickup service of goods (including express delivery) in Japan was collectively called Home delivery. "Takuhaibin" created by Yamato Transport was the unique service mode different from the traditional freight and express. This service model in 2000 was also called "home delivery" and "Takuhaibin" after being introduced by President Transnet Corporation and President Transnet Corporation. According to the study results of Yang (2007), Taiwan's five major home delivery companies were Chunghwa Post Company, President Transnet Corporation, Taiwan Pelican Express Company, Kerry TJ Logistics Company, HCT Logistics. Seen from the current market size of 20 billion NTD, B2C market still accounted for the bulk, whose proportion was close to ninety percent; $\mathrm{C} 2 \mathrm{C}$ market size was only ten percent. The two types of pathways were different. B2C was fixed point pickup and $\mathrm{C} 2 \mathrm{C}$ was closely related to collection passage. Because Kerry TJ Logistics and HCT Logistics operated B2C home delivery market, the number of receipts at this stage was not so important. Based on the above literature, comparison table of the five major home delivery companies was integrated in this study, as shown in Table 1:

Table1. Comparison Table of the Five Major Home Delivery Companies

\begin{tabular}{|c|c|c|c|c|c|c|}
\hline Project & $\begin{array}{c}\text { Restructuring or } \\
\text { Technical } \\
\text { Cooperation }\end{array}$ & $\begin{array}{l}\text { Major } \\
\text { Service } \\
\text { Items }\end{array}$ & $\begin{array}{c}\text { Main } \\
\text { Service } \\
\text { Object }\end{array}$ & $\begin{array}{l}\text { Passway } \\
\text { or } \\
\text { position }\end{array}$ & Advantages & $\begin{array}{c}\text { Disadvantage } \\
\mathrm{s}\end{array}$ \\
\hline $\begin{array}{c}\text { Chungh } \\
\text { wa Post } \\
\text { Compa } \\
\text { ny }\end{array}$ & $\begin{array}{l}\text { In 2003, the General } \\
\text { Administration of } \\
\text { Post Office was } \\
\text { transformed into state } \\
\text { ownership Chunghwa } \\
\text { Post Company }\end{array}$ & $\begin{array}{l}\text { Financia } \\
1, \text { postal } \\
\text { items }\end{array}$ & $\begin{array}{l}\text { B2C, } \\
\text { C2C }\end{array}$ & $\begin{array}{l}\text { Provincial } \\
\text { post office }\end{array}$ & $\begin{array}{l}\text { Lower prices, } \\
\text { a large } \\
\text { organization, } \\
\text { strong } \\
\text { positions, and } \\
\text { numerous } \\
\text { customers. }\end{array}$ & $\begin{array}{c}\text { Lower } \\
\text { convenience, } \\
\text { timeliness, less } \\
\text { wider } \\
\text { pathways than } \\
\text { supermarket } \\
\text { and limited } \\
\text { business hours. }\end{array}$ \\
\hline $\begin{array}{l}\text { Preside } \\
\text { nt } \\
\text { Transne } \\
\text { t } \\
\text { Corpora } \\
\text { tion }\end{array}$ & $\begin{array}{c}\text { Technical } \\
\text { cooperation of Uni- } \\
\text { President Enterprises } \\
\text { Corporation and } \\
\text { Yamato Transport } \\
\text { Co., and setting up } \\
\text { Kuroneko tkyubin in } \\
2000\end{array}$ & $\begin{array}{c}\text { Home } \\
\text { delivery }\end{array}$ & $\mathrm{C} 2 \mathrm{C}$ & 7-Eleven & $\begin{array}{c}\text { Higher } \\
\text { convenience } \\
\text { and } \\
\text { timeliness, } \\
\text { wide } \\
\text { pathways }\end{array}$ & $\begin{array}{l}\text { Higher price } \\
\text { and lower B2C } \\
\text { market share }\end{array}$ \\
\hline $\begin{array}{l}\text { Taiwan } \\
\text { Pelican } \\
\text { Express } \\
\text { Compa } \\
\text { ny }\end{array}$ & $\begin{array}{c}\text { Technical } \\
\text { cooperation of TECO } \\
\text { Group and Nippon } \\
\text { Express Co. in } 2000\end{array}$ & $\begin{array}{c}\text { Home } \\
\text { delivery }\end{array}$ & $\mathrm{C} 2 \mathrm{C}$ & $\begin{array}{l}\text { FamilyMa } \\
\text { rt, Hi-Life }\end{array}$ & $\begin{array}{l}\text { Convenience } \\
\text { and high } \\
\text { timeliness, } \\
\text { wide } \\
\text { pathways }\end{array}$ & $\begin{array}{l}\text { Higher price } \\
\text { and lower B2C } \\
\text { market share }\end{array}$ \\
\hline $\begin{array}{l}\text { Kerry } \\
\text { TJ } \\
\text { Logistic } \\
\text { s } \\
\text { Compa } \\
\text { ny }\end{array}$ & $\begin{array}{l}\text { T-JOIN and Hong } \\
\text { Kong Kerry Logistics } \\
\text { Network Limited } \\
\text { made networking } \\
\text { joint venture in } 2008\end{array}$ & $\begin{array}{l}\text { Logistic } \\
\mathrm{s} \text {, home } \\
\text { delivery }\end{array}$ & $\mathrm{B} 2 \mathrm{C}$ & $\begin{array}{l}\text { The } \\
\text { company's } \\
\text { cargo } \\
\text { positions }\end{array}$ & $\begin{array}{c}\text { Lower } \\
\text { B2C market } \\
\text { share and } \\
\text { lower } \\
\text { temperature } \\
\text { distribution }\end{array}$ & $\begin{array}{l}\text { Lower B2C } \\
\text { market share } \\
\text { and fewer } \\
\text { positions }\end{array}$ \\
\hline $\begin{array}{l}\text { HCT } \\
\text { Logistic } \\
\text { s } \\
\text { Compa } \\
\text { ny }\end{array}$ & $\begin{array}{c}\text { Technical } \\
\text { cooperation of HCT } \\
\text { Logistics Company } \\
\text { and Japanese Sagawa } \\
\text { Express Co. in } 2000\end{array}$ & $\begin{array}{l}\text { Logistic } \\
\mathrm{s} \text {, home } \\
\text { delivery }\end{array}$ & $\mathrm{B} 2 \mathrm{C}$ & $\begin{array}{l}\text { The } \\
\text { company's } \\
\text { cargo } \\
\text { positions }\end{array}$ & $\begin{array}{l}\text { High B2C } \\
\text { market share }\end{array}$ & $\begin{array}{l}\text { Lower B2C } \\
\text { market share } \\
\text { and fewer } \\
\text { positions }\end{array}$ \\
\hline
\end{tabular}

\subsection{Indicators of Affecting Factories for Home Delivery}

According to the data compiled by Liao and Lo (2013), Lin and Hsu (2009) and Ministry of Transportation and Communications (2004), the affecting factors can be divided into five facets: 


\subsubsection{Company Reputation}

It refers to the evaluation of customers in the business activities, including whether the object can be accurately delivered, what is the degree of professional staff, whether the quality of delivery is good, and whether corporate image is good.

\subsubsection{Convenience}

It refers to whether the industry can provide customers with more convenient way of consumption, including whether it can provide pickup service, whether the delivery time is acceptable, whether delivery location is convenient, and whether it can provide 24-hour service.

\subsubsection{Service Items}

It refers to the business items provided by the industry, including whether it can provide the insured services, whether it has the ability to deliver domestic and international delivery, whether it has cash on delivery collection fee, whether it can provide low-temperature distribution services.

\subsubsection{Price}

It refers to the fees charged by the business under different service contents, including whether the lowest delivery price, that is the basic price is reasonable, whether it can provide a single price discount program with a relatively low single price for a certain weight and volume, whether it can provide large discount program, and whether it can provide long-term enterprise cooperation program.

\subsubsection{Timeliness}

It refers to the ability of the practitioners to complete the delivery within an agreed time, including whether it can provide holiday delivery services, whether it can provide night delivery services, and whether it has the ability of providing fast service.

\subsection{Modified Delphi Method}

The modified Delphi method was proposed by Murry and Hommons (1995). Its processes and statistical methods were changed from the traditional Delphi method and their practices were similar. It preserved the spirits and practices of the traditional Delphi method, allowing the experts to use anonymous semi-open 1uestionnaires to communicate the views, simplify the cumbersome questionnaire steps, and change the questionnaire contents of the first round directly to the relevant research results in the reference. The way of expert interviews may also be obtained to develop a structured questionnaire as the questionnaire of the first round, which made the research work carried out quickly, saved a lot of time, and allowed the experts to reduce the discussion and speculation on open questionnaires on research topics, improve the questionnaire recovery rate more effectively, and achieve consistency consensus.

\subsection{Analytic Hierarchy Process}

The analytic hierarchy process was a set of decision-making methods developed by University of Pittsburgh Professor Thomas L. Saaty in 1971, which was mainly used on decision-making issues with multiple assessment criteria in uncertain situations (Tseng and Teng, 1995). It analyzed complex problems according to different layers to make it systematic and simple. In the study, complex problems were factorized according to their nature to form a tree structure and establish mutual impact layers. Through the paired comparison of each element and layer, the weight value of elements of each layer was obtained, finally the comprehensive evaluation was made, the merits and demerits of each layer were compared, and the results would provide reference for decision making.

\section{ReSEARCh Method}

In this study, the research reports of relevant scholars at home and abroad were collected and discussed in the way of literature review. After the discussion with experts, the criteria of the preliminary decision-making factors were evaluated and the modified Delphi expert questionnaire was conducted to determine the hierarchical structure. Then the decision-making factors were ranked according to the importance degree with the analytic hierarchy process. 


\subsection{Document Analysis}

The relative studies of domestic and foreign scholars were searched. The reports of Liao and Lo (2013), Lin and Hsu (2009) and Ministry of Transportation and Communications et al. (2004) were studied and the services provided by current home delivery companies were integrated. The preliminary assessment criteria layers were shown in Table 2.

Table2. Preliminary Assessment Criteria Layer

\begin{tabular}{|c|c|c|}
\hline The First Layer & The Second Layer & The third Layer \\
\hline Goal & Main Criteria & Secondary Criteria (assessment criteria) \\
\hline \multirow{19}{*}{$\begin{array}{l}\text { Key Selection Criteria for } \\
\text { Successful Management of } \\
\text { Home Delivery }\end{array}$} & \multirow[t]{4}{*}{ Company reputation } & Accurate delivery \\
\hline & & Professional degree \\
\hline & & Delivery quality \\
\hline & & Corporate image \\
\hline & \multirow[t]{4}{*}{ Convenience } & Pickup service \\
\hline & & Time of delivery \\
\hline & & Place of delivery \\
\hline & & 24-hour service \\
\hline & \multirow[t]{4}{*}{ Service items } & Insured service \\
\hline & & Domestic and international delivery \\
\hline & & Price collection service \\
\hline & & Low-temperature distribution \\
\hline & \multirow[t]{4}{*}{ Price } & Basic price \\
\hline & & Single price discount program \\
\hline & & Large discount program \\
\hline & & Long-term enterprise cooperation program \\
\hline & \multirow[t]{3}{*}{ Timeliness } & Holiday delivery \\
\hline & & Night delivery \\
\hline & & Fast service \\
\hline
\end{tabular}

\subsection{Modified Delphi Expert Questionnaire Design}

According to Hwan and Lin (1987), the response rate of the questionnaire would decrease due to the increase in the number of repeated surveys. While Green, Hunter, and Moore et al. (1990) also believed that the number of questionnaires between 2 and 3 was sufficient to reach a consensus (Teng, 2013). Therefore, this study fixed the number of modified Delphi questionnaires within three times (Teng, 2013). According to John Dawes (2008), empirical studies found empirical data based on the Likert 5-point scale, such as the statistic of mean value, variance and standard deviation only had a very small difference. Therefore, this study used the Likert 5-point scale in the form of closed questionnaires, and the degree of importance is divided into [Very unimportant], [Unimportant], [Fair], [Important], [Very Important], which were given 1 point, 2 points, 3 points, 4 points and 5 points, respectively to show the experts' degree of attention for the assessment project. The first modified Delphi questionnaire was a semi-open structured questionnaire based on the content of preliminary assessment criteria layers, according to the Likert 5-point scale. The second modified Delphi questionnaire was an open structured questionnaire based on the results of first modified Delphi questionnaire and experts' opinions. The hierarchical structure was established when experts' opinions were consistent.

Delbecq et al. (1975) argued that the number of modified Delphi expert groups had better to be 5 to 9 , and achieved consensus and objectification of experts' opinions after repeated discussion and decision. Therefore, in order to obtain professional and effective results, the invited experts included 9 professionals above the supervisor level of Chunghwa Post Company, home delivery companies and logistics companies with at least 10 years of working experience. They formed the modified Delphi expert groups together to assist the questionnaire survey of the study.

\subsection{Hierarchical Analysis of Customer Questionnaire Design}

It took the hierarchical structure established by the modified Delphi method as the content and adopted nine-grade rating scale suggested by Satty (1980). Under the basis of the assessment, paired comparisons were made between scale 1 to 9 to design the AHP customer questionnaire. The hierarchical analysis of the choice of questionnaire object was essential, so different questionnaire objects would have different results. In order to minimize the uncertainty factors 
and make the questionnaire data accurately respond the purpose of this study, a representative sample was taken as the subject of this study, which was different from the general random sampling method. Since the main subject of this study was the online store and the general customers, and the times of goods sent by online stores was more frequent than general customers, 20 owners of online shops located in Miaoli County were chosen as the subjects of the questionnaire. In addition, the general customer's opinion was also very important, but too scattered, so this study took operators of postal articles in the post office, convenient stores and freight company business unit in Miaoli County as the Post office and convenient supermarkets, freight company business unit is responsible for handling postal goods handling staff as the subjects of the questionnaire. After many visits, ten handling personnel were selected as the subjects of the questionnaire. The total number of subjects in the hierarchical analysis customer questionnaires was 30. The pairwise comparison matrix was established through paired comparison of each factor in the layers; the characteristic vector and the maximum weight value were calculated and the consistency test was carried out; and the overall evaluation factor weight was calculated, according to the degree of importance.

\section{ReSUlts ANALYSIS}

\subsection{Results of Modified Delphi Method}

There were five main criteria and nineteen secondary criteria in the first modified Delphi questionnaire. Subjects in the questionnaire included five main criteria and 19 secondary criteria. The questionnaire subjects included 9 professionals above the supervisor level of state-owned businesses, home delivery companies and logistics companies with at least 10 years of working experience. The number of actual recovery questionnaires was 9 , and the recovery rate was $100 \%$. According to Chen and Chen (2011) in the Journal of Humanities and Social Sciences, there were five levels in the Likert scale. If the middle result was "3", it was general. Therefore, to integrate the overall consent degree of experts, if the level of results was limited to over "3.5", it was thought that all experts and scholars reached a consensus. If standard deviation was larger than 1 , the dispersion of opinions was large, so it should be deleted. According to the standard proposed by Chang et al. (2002), when According to the standard proposed by Chang et al. (2002), when $\mathrm{CV} \leqq 0.3$, it meant that the experts and scholars reached a high degree of consistent consensus; and when $0.3 \leqq \mathrm{CV} \leqq 0.5$, it indicated that the expert scholar was in the acceptable range; when $\mathrm{CV} \geqq 0.5$, it must explain the reasons.

The results of first modified Delphi questionnaire deleted the 2 secondary criteria of professional degree and time of delivery; at the same time, in the returned questionnaires, some experts recommended to join damage compensation in the secondary criteria under the main criteria of "corporate reputation". The project was the most prone to a dispute, which may cause damage on the company's credibility. There were 5 main criteria and 18 secondary criteria joined in the second modified Delphi questionnaire. The result deleted insured service and reserved 5 main criteria and 17 secondary criteria.

Table3. Assessment Criteria Layers

\begin{tabular}{|c|c|c|}
\hline The First Layer & The Second Layer & \begin{tabular}{|l|} 
The third Layer \\
\end{tabular} \\
\hline Goal & Main Criteria & Secondary Criteria (assessment criteria) \\
\hline \multirow{17}{*}{$\begin{array}{l}\text { Key Selection Criteria for } \\
\text { Successful Management of } \\
\text { Home Delivery }\end{array}$} & \multirow[t]{4}{*}{ Company reputation } & Accurate delivery \\
\hline & & Professional degree \\
\hline & & Delivery quality \\
\hline & & Corporate image \\
\hline & \multirow[t]{3}{*}{ Convenience } & Pickup service \\
\hline & & Place of delivery \\
\hline & & 24-hour service \\
\hline & \multirow[t]{3}{*}{ Service items } & Domestic and international delivery \\
\hline & & Price collection service \\
\hline & & Low-temperature distribution \\
\hline & \multirow[t]{4}{*}{ Price } & Basic price \\
\hline & & Single price discount program \\
\hline & & Large discount program \\
\hline & & Long-term enterprise cooperation program \\
\hline & \multirow[t]{3}{*}{ Timeliness } & Holiday delivery \\
\hline & & Night delivery \\
\hline & & Fast service \\
\hline
\end{tabular}




\subsection{Results of Analytic Hierarchy Process}

There were 29 effective returned questionnaires and the recovery rate was $96 \%$. This stratification questionnaire was conducted by Satty (1980), which recommended the use of nine-grade rating scale. Under the basis of the assessment, paired comparisons were made between scale 1 to 9.9 and other scale scales, from the scale of 1 to 9 According to the results of the questionnaire, the pairwise comparison matrix was established to get the consistency of eigenvalues and eigenvectors. Then consistency of the matrix was checked and relative values were analyzed by Excel. The data acquisition principle was based on the consistency criterion of the hierarchy proposed by Saaty. CI value $\leqq 0.10$ meant the tolerable error. In addition, the consistency ratio CR was used as the criterion to measure the consistency of pair contrast matrix. Saaty assumed that $\mathrm{CR} \leqq 0.1$ meant that the pair contrast matrix was reasonable within a certain range and the decision behavior could continue. When CR> 0.1 , it may be judged as a random pattern, and the comparison matrix must be reevaluated.

\subsubsection{Analysis Results of the Main Criteria Weight in the Second Layer}

Table 4 was the results of the questionnaires, which showed that for customers, the most important in the main criteria was the price, followed by timeliness, service items, convenience and the company's reputation.

Table4. Analysis Results of the Main Criteria Weight in the Second Layer

\begin{tabular}{|c|c|c|}
\hline Main Criteria & Relative weight & Weight order \\
\hline Company Reputation & 0.167 & 5 \\
\hline Convenience & 0.181 & 3 \\
\hline Service items & 0.212 & 1 \\
\hline Price & 0.223 & 2 \\
\hline Timeliness & 0.217 & \\
\hline \multicolumn{2}{|c|}{ C.I. $=0.049<0.1 ;$ C.R. $=0.044<0.1$ Conform to the consistency criteria. } \\
\hline
\end{tabular}

4.2.2. Analysis Results of the Secondary Criteria Weight of Corporate Reputation in the Third Layer

Table 5 was the results of the questionnaires, which showed that for customers, the most important in the corporate reputation of the secondary criteria was accurate delivery, followed by damage compensation, delivery quality and corporate image.

Table5. Analysis Results of the Secondary Criteria Weight of Corporate Reputation in the Third Layer

\begin{tabular}{|c|c|c|}
\hline Secondary Criteria & Relative weight & Weight order \\
\hline Accurate delivery & 0.630 & 1 \\
\hline Damage compensation & 0.140 & 2 \\
\hline Delivery quality & 0.135 & 3 \\
\hline Corporate image & 0.095 & 4 \\
\hline \multicolumn{2}{|r|}{ C.I. $=0.019<0.1 ;$ C.R. $=0.021<0.1$ Conform to the consistency criteria. } \\
\hline
\end{tabular}

\subsubsection{Analysis Results of the Secondary Criteria Weight of Convenience in the Third Layer}

Table 6 was the results of the questionnaires, which showed that for customers, the most important in the convenience of the secondary criteria was 24-hour service, followed by place of delivery and pickup service.

Table6. Analysis Results of the Secondary Criteria Weight of Convenience in the Third Layer

\begin{tabular}{|c|c|c|}
\hline Secondary Criteria & Relative weight & Weight order \\
\hline Pickup service & 0.104 & 3 \\
\hline Place of delivery & 0.446 & 2 \\
\hline 24-hour service & 0.450 & 1 \\
\hline \multicolumn{2}{|c|}{ C.I. $=0.08<0.1 ;$ C.R. $=0.013<0.1$ Conform to the consistency criteria. } \\
\hline
\end{tabular}

\subsubsection{Analysis Results of the Secondary Criteria Weight of Service Items in the Third Layer}

Table 7 was the results of the questionnaires, which showed that for customers, the most important in the service items of the secondary criteria was 24-hour service, followed by domestic and international delivery and the last was low-temperature distribution. 
Discussion on Key Selection Criteria For Successful Management Of Home Delivery

Table7. Analysis Results of the Secondary Criteria Weight of Service Items in the Third Layer

\begin{tabular}{|c|c|c|}
\hline Secondary Criteria & Relative weight & Weight order \\
\hline Domestic and international delivery & 0.434 & 2 \\
\hline Price collection service & 0.446 & 1 \\
\hline Low-temperature distribution & 0.120 & 3 \\
\hline \multicolumn{2}{|c|}{ C.I. $=0.013<0.1 ;$ C.R. $=0.023<0.1$ Conform to the consistency criteria. } \\
\hline
\end{tabular}

\subsubsection{Analysis Results of the Secondary Criteria Weight of Price in the Third Layer}

Table 8 was the results of the questionnaires, which showed that for customers, the most important in the price of the secondary criteria was basic price, followed by single price discount program, long-term enterprise cooperation program and large discount program.

Table8. Analysis Results of the Secondary Criteria Weight of Price in the Third Layer

\begin{tabular}{|c|l|l|}
\hline Secondary Criteria & Relative weight & Weight order \\
\hline Basic price & 0.452 & 1 \\
\hline Single price discount program & 0.371 & 2 \\
\hline Large discount program & 0.087 & 4 \\
\hline Long-term enterprise cooperation program & 0.090 & 3 \\
\hline C.I. $=0.008<0.1 ;$ C.R. $=0.009<0.1$ Conform to the consistency criteria. \\
\hline
\end{tabular}

\subsubsection{Analysis Results of the Secondary Criteria Weight of Timeliness in the Third Layer}

Table 9 was the results of the questionnaires, which showed that for customers, the most important in the timeliness of the secondary criteria was fast service, followed by night delivery and holiday delivery.

Table9. Analysis Results of the Secondary Criteria Weight of Timeliness in the Third Layer

\begin{tabular}{|c|c|c|}
\hline Secondary Criteria & Relative weight & Weight order \\
\hline Holiday delivery & 0.243 & 3 \\
\hline Night delivery & 0.282 & 2 \\
\hline Fast service & 0.475 & 1 \\
\hline \multicolumn{2}{|c|}{ C.I. $=0.011<0.1$; C.R. $=0.019<0.1$ Conform to the consistency criteria. } \\
\hline
\end{tabular}

\subsubsection{Main Criteria and Secondary Criteria Weight Analysis}

The order of main criteria and secondary criteria weight were shown in Table 10.

Table10. Weight Analysis

\begin{tabular}{|c|c|c|c|c|c|c|}
\hline Goal & $\begin{array}{c}\text { Main } \\
\text { Criteria }\end{array}$ & $\begin{array}{c}\text { Main Criteria } \\
\text { Weight }\end{array}$ & Secondary Criteria & $\begin{array}{c}\text { Secondary } \\
\text { Criteria } \\
\text { Weight }\end{array}$ & $\begin{array}{c}\text { Comprehensive } \\
\text { Weight }\end{array}$ & Ranking \\
\hline \multirow{17}{*}{$\begin{array}{c}\text { Key } \\
\text { Selection } \\
\text { Criteria for } \\
\text { Successful } \\
\text { Management } \\
\text { of Home } \\
\text { Delivery }\end{array}$} & \multirow{4}{*}{$\begin{array}{l}\text { Company } \\
\text { Reputation }\end{array}$} & \multirow{4}{*}{0.167} & Accurate delivery & 0.630 & 0.1052 & 1 \\
\hline & & & Damage compensation & 0.140 & 0.0233 & 12 \\
\hline & & & Delivery quality & 0.135 & 0.0225 & 13 \\
\hline & & & Corporate image & 0.095 & 0.0158 & 17 \\
\hline & \multirow{3}{*}{ Convenience } & \multirow{3}{*}{0.181} & Pickup service & 0.104 & 0.0188 & 16 \\
\hline & & & Place of delivery & 0.446 & 0.0807 & 8 \\
\hline & & & 24-hour service & 0.450 & 0.0814 & 7 \\
\hline & \multirow{3}{*}{$\begin{array}{l}\text { Service } \\
\text { Items }\end{array}$} & \multirow{3}{*}{0.212} & $\begin{array}{c}\text { Domestic and } \\
\text { international delivery }\end{array}$ & 0.434 & 0.0920 & 5 \\
\hline & & & Price collection service & 0.446 & 0.0945 & 4 \\
\hline & & & $\begin{array}{c}\text { Low-temperature } \\
\text { distribution }\end{array}$ & 0.120 & 0.0254 & 11 \\
\hline & \multirow{4}{*}{ Price } & \multirow{4}{*}{0.223} & Basic price & 0.452 & 0.1007 & 3 \\
\hline & & & $\begin{array}{c}\text { Single price discount } \\
\text { program }\end{array}$ & 0.371 & 0.0827 & 6 \\
\hline & & & Large discount program & 0.087 & 0.0194 & 15 \\
\hline & & & $\begin{array}{l}\text { Long-term enterprise } \\
\text { cooperation program }\end{array}$ & 0.090 & 0.0200 & 14 \\
\hline & \multirow{3}{*}{ Timeliness } & \multirow{3}{*}{0.217} & Holiday delivery & 0.243 & 0.0527 & 10 \\
\hline & & & Night delivery & 0.282 & 0.0611 & 9 \\
\hline & & & Fast service & 0.475 & 0.1030 & 2 \\
\hline
\end{tabular}


The key selection factory that affected customers' choice of home delivery was price, followed by timeliness, service items, convenience and company's reputation. The study believed that price played a vital role in any marketplace of competitive activities, but the difference of price which ranked the first, timeliness which ranked the second and service items which ranked the third was small. It was clear that the price in this study was not an absolute key factor, but relatively more important compared with other decision-making factors. Besides, the importance of timeliness reflected the current emphasis on high efficiency of the timeliness; in the fast pace of life, time was money. In many cases, delivery was a very important condition in accordance with the specified time. In network sales, quick delivery meant remuneration for quick completion of the transaction. Service items can reflect the ability of enterprises to capture customers' demands, so it was also particularly important. Weight of the above three main criteria accounted for $65.2 \%$, so this study listed the three factors that affected customers' selection of home delivery. In the aspects of convenience and reputation of company, although they were also important compared to the key factors, they were less important.

\section{Conclusion}

In this paper, the following conclusions are obtained from the empirical analysis. In the main criterion, according to the two modified Delphi questionnaires, there are five main criteria, which are the company's reputation, convenience, service items, price and timeliness. After the analysis of hierarchy analysis, in the main criteria, the most important is the price, followed by timeliness, service items, convenience and company's reputation. The results are further analyzed; the weight of price, timeliness, and service accounts for $65.2 \%$, so they are regarded as the key factors that impact customers' choice of home delivery and the specific direction for review and future improvement of home delivery.

In the aspect of secondary criteria, through the analysis of analytic hierarchy process, the order of importance of secondary criteria is as follows: 1 accurate delivery, 2 quick service, 3 basic price, 4 price collection service, 5 domestic and international delivery, 6 single discount program, 724 hour service, 8 place of delivery, 9 night delivery, 10 holiday delivery, 11 low-temperature distribution, 12 damage compensation, 13 delivery quality, 14 long-term enterprise cooperation program, 15 large discount program, 16 pick-up service, 17 corporate image. It is analyzed based on the result that the comprehensive weight of the top ten decision factors is $85.4 \%$ of the total weight. Therefore, the first ten secondary criteria are listed as the key factors influencing the customers' selection of home delivery and the specific direction for review and future improvement of home delivery. It is worth mentioning that for the overall business of home delivery, large customers and long-term customers should be the priority subjects, but they are limited by the research goals of this study. Thus, it can be expected that the importance of some cooperative scheme aimed at large customers and long-term customers like long-term enterprise cooperation program, large discount program and pick-up service is relatively low.

The suggestion given by this study is that timeliness and convenience are the most competitive projects for home delivery practitioners. If there is more flexibility space for price, it will help enhance the performance and the give strong pressure on competitors. Furthermore, with the advantages of $\mathrm{C} 2 \mathrm{C}$ market, home delivery practitioners can also try to enter $\mathrm{B} 2 \mathrm{C}$ market and expand the scope of business. The suggestion for logistics companies is that the master of B2C market is the advantage of the logistics industry, so it is feasible to expand business of $\mathrm{C} 2 \mathrm{C}$ market on this basis. However, in the face of $\mathrm{C} 2 \mathrm{C}$ market with scattered customers, it is necessary to make appropriate adjustments in price, timeliness, service items and convenience, especially the convenience of the place of delivery, so that it can content with other competitors.

\section{REFERENCES}

[1] Chen, W.L., Chen, T.H. (2011). Research on the Construction of Closing Design Indicators by Using Modified Delphi Method, Journal of Humanities and Social Sciences, 7: 1, 49-59.

[2] Chang,p.C.,Tsou,N T.,Yuan,B. J. C.,\& Huang,C. C. (2002), Development Trends in Taiwan's Opto-electronics Industy,Technovation,22, 161-173.

[3] Lin, C.S., Hsu, C.L. (2009). Reveal of Secret of successful Home Delivery. Quality Magazine, 45(3), 40-41. 
[4] Liao, T.Y., Lo, Y. (2013). Analysis on the Service Quality and Customer Satisfaction of Home Delivery Industry - Taking Taiwan's Five Major Home Delivery Business as an Example. Journal of E-Business, 15(4), 475.

[5] Ministry of Transportation and Communications (2004). National Freight Development Policy White Paper, Ministry of Transportation and Communications.

[6] Murry J.W., and J.O. Hammons, (1995), "Delphi: A versatile methodology for conductingqualitative research," The Review of Higher Education, vol. 18, no. 4,p. 423-436.

[7] Saaty, T. L. (1980).The Analytic Hierarchy Process. New York: McGraw-Hill. Inc. 40.

[8] Teng, C.H. (2013). Using Modified Delphi Method and AHP to Evaluate of Bancassurance Sales Competence Indicators in Taiwan. Master's Thesis, Department of Insurance Master Class of Insurance Management, Tamkang University

[9] Teng, C.Y., Tseng, K.H. (1989). Connotation Characteristics and Application of Analytic Hierarchy Process (Upper). Journal of the Chinese Statistical Association, 27(6), 5-22.

[10] Yang, M.H. (2007). The Rising of Home Delivery Industry with many new Shopping Channels-- Perspective of Taiwan's Five Home Delivery Business. Wealth Magazine, 300.

\section{AUTHOR'S BIOGRAPHY}

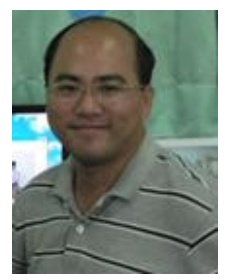

My name is Yi-Hsueh Shen, I live in Miaoli Taiwan. I worked as a local tour guide from 1997 to 2000. I went to American to get my master degree in Fairleigh Dickinson University together with my wife. It brought me a beautiful time in my life in New Jersey during 2001 2002. After I came back to Taiwan, I have been a teacher in the department of Hospitality Management in Jen-teh Junior College of Medicine, Nursing and Management.

My major is business administration and specialties are management, marketing, consumer behavior, human resource management etc. I am the Dean of student affairs in the school that is responsible for planning extracurricular activities for the students every semester. This position needs the abilities of well communication and be energetic and enthusiastic. I believe people are born to take responsibilities and I hope to continue to keep growing in academic field with my students and colleagues around me. 